doi: $10.37321 /$ nefrology.2019.25-14

УДК 616.61

\title{
ВПРОВАДЖЕННЯ МІЖНАРОДНИХ КЛІНІЧНИХ НАСТАНОВ У ПРАКТИКУ
}

\section{(за матеріалами 13-го Міжнародного післядипломного курсу ERA-EDTA: нефрологічна академія REENA)}

Резюме.

\begin{abstract}
13 вересня 2019 року в м. Ірпінь Київської обл. відбувся 13-ий Міжнародний післядипломний курс ERA-EDTA: нефрологічна академія REENATм 2019 «Bacкуліти у дітей та дорослих: розвиток, перебіг, лікування, спостереження». 3 доповідями виступили професор Дмитро Іванов (вовчаковий нефрит у дітей: від підлітка до дорослого), професор Олег Яременко (імунобіологічне лікування при системному некротичному васкуліті) та представники їх кафедр з доповідями про IgA нефропатію, синдром Гудпасчера, саркоїдоз, ідіопатичну тромбоцитопенічну пурпуру та ін.
\end{abstract}

Ключові слова: післядипломна освіта, ураження нирок, нефрологія, ревматологія.

Під егідою Української Асоціації педіатрівнефрологів (Ukrainian Association of Pediatric Nephrologists - UAPN), Міжнародної педіатричної асоціації нефрологів (International Pediatric Nephrology Association - IPNA), Національної медичної академії післядипломної освіти імені П.Л. Шупика 13 вересня в - Конференц-залі Гранд Адмірал клубу Ірпінь (м. Ірпінь Київської обл.) відбувся 13-ий Міжнародний післядипломний курс ERA-EDTA: нефрологічна академія REENATM 2019 (Східно-Європейська Ниркова академія) «Васкуліти у дітей та дорослих: розвиток, перебіг, лікування, спостереження».

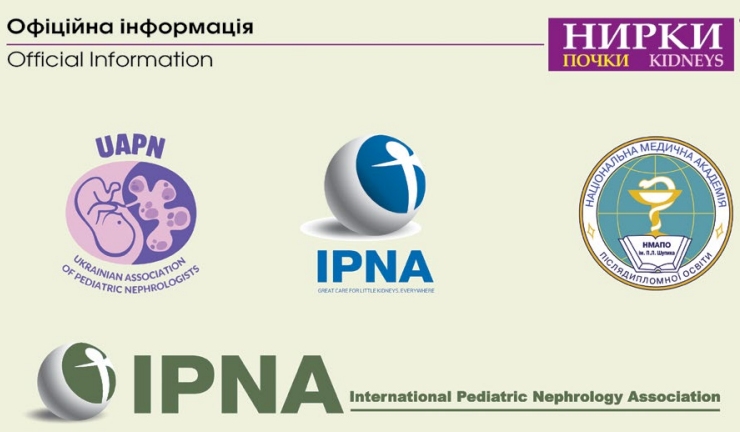

ПРОГРАМА КУРСУ

ЩорічниЙ 13-й КУрс пісАЯАИП^ОМної Освіти REENATM (СхіАноєвропейська ниркова акаАемія)

ВАСКУАІТИ У АІТЕЙ ТА АОРОСАИХ: РОЗВИТОК, ПЕРЕБІГ, АІКУВАННЯ, СПОСТЕРЕЖЕННЯ

Усі зірки ревматології України сьогодні з нами! 13 вересня 2019 року (перший день)

Місце проведення: конференц-зал Grand Admiral Resort \& SPA (вул. Варшавська, 116, Ірпінь, Київська обл., Україна)

09:30. Урочиста церемонія відкриття

Офіційний представник адміністрації нмАпо імені п.л. Шупика -

академік НАМН Любомир Антонович Пиріг (Київ, Україна)

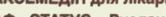

Мал.1. Програма 13-ого Міжнародного післядипломного курсу ERA-EDTA: нефрологічна академія REENATM 2019

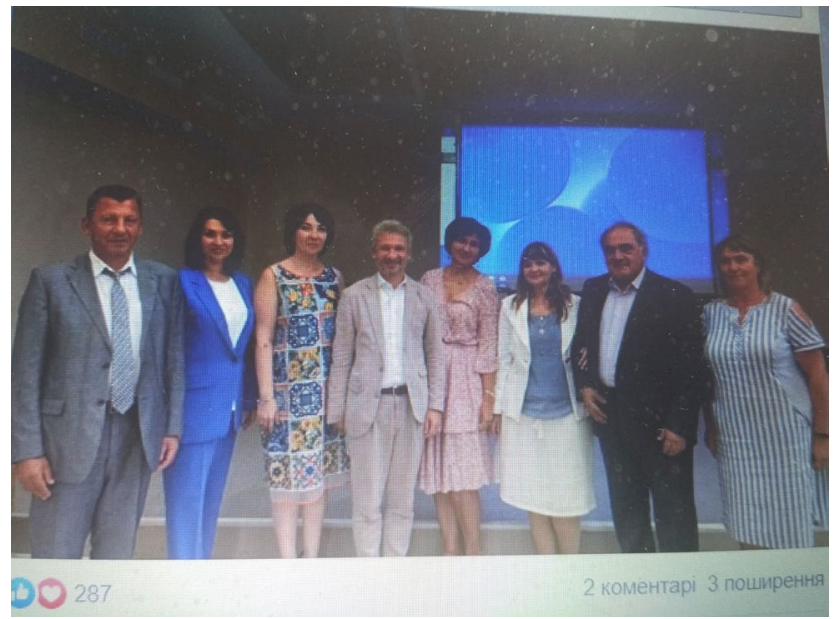

Мал. 2. Проф. О.Б. Яременко, д.м.н. Т.Б. Бевзенко, проф. Є.Д. Єгудіна, проф. Д.Д. Іванов, проф. І.Ю. Головач, проф. О.О. Дядик, к.м.н. С.Х. Тер-Вартанян, проф. В.О. Мойсеєнко під час роботи Східно-Європейської Ниркової академії REENA_2019

3 привітальним словом по скайпу учасників школи привітав академік АМН України доктор медичних наук, професор кафедри нефрології і нирково-замісної терапії НМАПО імені П.Л. Шупика Л.А. Пиріг. Під час освітянського курсу присутні ознайомилися з основними положеннями нових керівництв KDIGO. У конференції взяв участь О.М. Цигин, д.мед.н., професор, завідувач дитячого нефрологічного центру «Науковий центр здоров'я дітей» Російської академії медичних наук (Москва, Російська Федерація), член IPNA, який представив 2 доповіді - «Вовчаковий нефрит у дітей» і «ANCA васкуліт у дітей».

Основні постулати оновлених рекомендацій по веденню пацієнтів з гломерулонефритами виклав у своїй доповіді «Вовчаковий нефрит у дітей: від підлітка до дорослого» Д.Д. Іванов, президент УАДН, д.мед.н., проф., завідувач кафедри нефрології та НЗТ НМАПО імені П.Л.Шупика (Київ, Україна), член IPNA, який зупинився на 
питанні щадного застосування кортикостероїдів. Морфологічно спрямованими та добре ілюстрованими були доповіді д.мед.н., проф. завідувачки кафедри патологічної та топографічної анатомії НМАПО імені П.Л. Шупика О.О. Дядик, (Київ, Україна) «Патоморфологія та її зв'язок із сучасною імуносупресією», «Патоморфологія ANCA васкуліту та сучасна імуносупресія» та «Що можна отримати з регіональних реєстрів: ураження нирок при системній склеродермії та хвороби Шегрена».

Відомим в Україні та за їі межами ревматологом, д.мед.н., проф. завідувачем кафедри внутрішньої медицини № 3 Національного медичного університету О. О. Богомольця професором Яременко О.Б. (Київ, Україна) викладено бачення на імунобіологічне лікування при системному некротичному васкуліті та наведені приклади з заархівованого спостереження «IgA нефропатія: огляд понад 500 випадків». 3 етіологією, патогенезом, клінічними проявами синдрома Гудпасчера ознайомила С.В. Кушніренко, к.мед.н. доц., декан терапевтичного факультету Національної медичної академії післядипломної освіти П.Л.Шупика (Київ, Україна), на особливостях клінічного перебігу синдрому Гудпасчера у підлітків і дорослих акцентував увагу присутніх Ю.В. Одинець, д.мед.н., проф., Харківська медична академія післядипломної освіти (Харків, Україна).

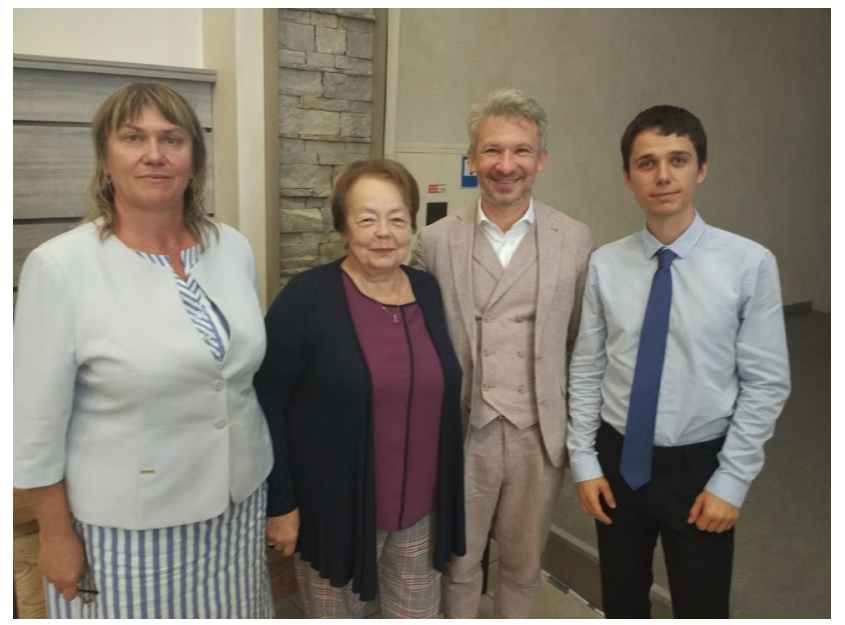

Мал. 3. Проф. Мойсеєнко В.О., доц.Таран О.І., проф. Д.Д. Іванов з молодим науковцем із Дніпра.

Ця школа показала дієву співпрацю українських нефрологів і ревматологів. Цікавими та дискусійними для аудиторії виявилися виступи С.Х. Тер-Вартаняна, д.м.н., доцента, Клініка сучасної ревматології (Київ, Україна) - «Геморагічний васкуліт та пурпура Геноха - Шенлейна», Т.Б. Бевзенко, д.мед.н, доцент кафедри нефрології та НЗТ Національної медичної академії післядипломної освіти ім. П.Л.Шупика (Київ, Україна) - «Анкілозуючий спондиліт, псоріаз та ураження нирок», С.О. Ротової, к.мед.н, до- цент кафедри нефрології та НЗТ Національної медичної академії післядипломної освіти ім. П.Л.Шупика (Київ, Україна) - «Саркоїдоз із ураженням нирок», Т.В. Будник, к.мед.н., доц. кафедри нефрології та НЗТ Національної медичної академії післядипломної освіти ім. П.Л.Шупика, м. Київ, Україна, яка навела рідкісне клінічне спостереження за захворюванням нирок у 17-річного пацієнта з ідіопатичною тромбоцитопенічною пурпурою.

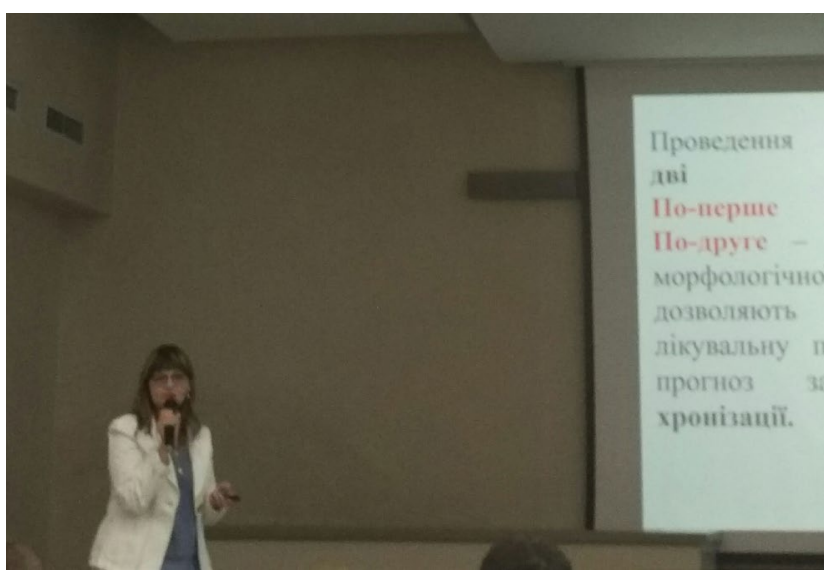

Мал. 4. Виступає проф. О.О. Дядик.

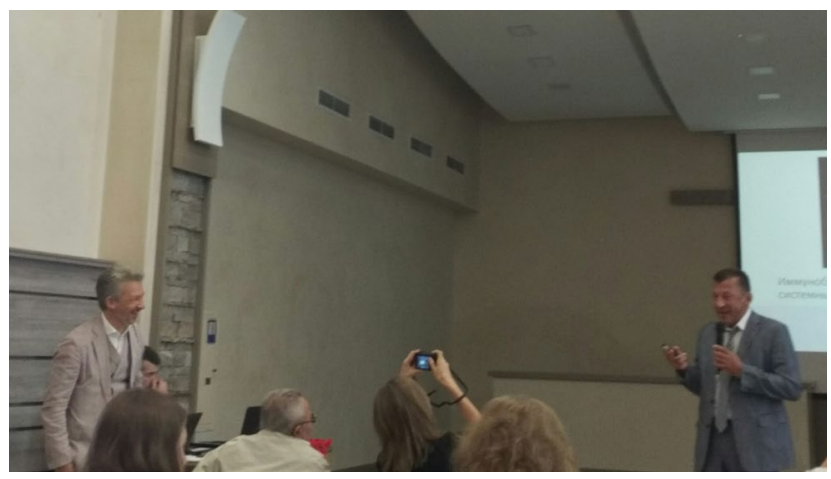

Мал. 5. Дискусія проф. Д.Д. Іванов проф. О.Б. Яременко (Україна).

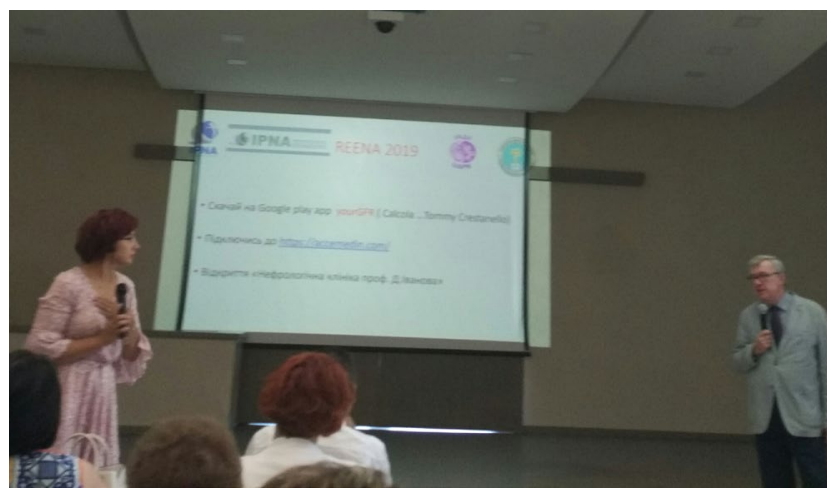

Мал. 6. Дискусія проф. І.Ю. Головач (Україна) проф. О.М. Цигин (Росія) 
Наступного дня засідання відбувалися в нефрологічній клініці проф. Д. Іванова, де були наведені клінічні випадки васкулітів та розібрані питання їх ранньої протеомічної, генетичної та патоморфологічної діагностики та лікування (проф. О.О. Дядик та член УАДН, д.мед.н., кандидат університетів Мілано Бікокка (Мілан, Італія) Марія Іванова), а також для цільової аудиторії практикуючих лікарів надані корисні практичні поради щодо альтернативної терапії при інфекціях сечових шляхів, генетичних захворюваннях, гострому ураженні нирок, основних моментах в лікуванні гіпертензії у нефрологічних хворих 3 позицій доказової медицини.

Доц. Ротова C.O., доц.Таран Ол-р І., доц. Таран О.І.

\section{РЕЗЮME}

\section{ВНЕДРЕНИЕ МЕЖДУНАРОДНЫХ КЛИНИЧЕСКИХ РЕКОМЕНДАЦИЙ В ПРАКТИКУ}

(По материалам 13-го Международного курса ERAEDTA: нефрологическая академия REENA)

Ротова С.А., Таран А.И., Таран Е.И (Киев)

13 сентября 2019 года в г. Ирпень Киевской обл. состоялся 13 Международный последипломный курс ERA-EDTA: нефрологическая академия REENATм 2019 «Васкулиты у детей и взрослых: развитие, течение, лечение, наблюдение».

С докладами выступили профессор Дмитрий Иванов (волчаночный нефрит у детей от подростка к взрослому), профессор Олег Яременко (иммунобиологическое лечение при системном некротическом васкулите) и представители их кафедр с докладами о $\lg$ А нефропатии, синдроме Гудпасчера, саркоидозе, идиопатической тромбоцитопенической пурпуре и др.

Ключевые слова: последипломное образование, поражение почек, нефрология, ревматология.

\section{SUMMARY}

KDIGO GUIDELINES IMPLEMENTATION IN PRACTICE (13th International Postgraduate Education Course ERA-EDTA: Nephrology Academy REENA)

Rotova S.O., Taran O.I., Taran E.I.

$$
\text { (Kyiv) }
$$

On the 13th September 2019, in Irpin, Ukraine, there was held a 13th International Postgraduate Course ERAEDTA: REENATM 2019 Nephrology Academy "Vasculitis in children and adults: development, course, treatment, observation" supported by National Medical Academy of Postgraduate Education with basic department of $\mathrm{Ne}$ phrology and RRT (Local Coordinator is Prof. Dmytro Ivanov, the Nephrology and RRT Department Chief) was held.

The reports were presented by Professor Dmytro Ivanov (lupus nephritis in children from adolescent to adult), Professor Oleg Yaremenko (immunobiological treatment for systemic necrotic vasculitis), and representatives of their departments with reports on IgA nephropathy, Gudpapzeceric syndrome at al.

Key words: postgraduate education, kidney damage, nephrology, rheumatology.

\section{Ротова Світлана Олексіївна} rotova@ukr.net 